\title{
Evaluation of the CDC safe water-storage intervention to improve the microbiological quality of point-of-use drinking water in rural communities in South Africa
}

\author{
N Potgieter ${ }^{1 *}$, PJ Becker ${ }^{2,3}$ and MM Ehlers ${ }^{4,5}$ \\ ${ }^{1}$ Dept of Microbiology, University of Venda, Thohoyandou, Private Bag X5050, Thohoyandou, 0950, Limpopo Province, South Africa \\ ${ }^{2}$ MRC, Pretoria, Gauteng Province, South Africa \\ ${ }^{3}$ Division of Clinical Epidemiology, University of Pretoria, Gauteng Province, South Africa \\ ${ }^{4}$ Dept of Medical Microbiology, University of Pretoria, Gauteng Province, South Africa \\ ${ }^{5}$ National Health Laboratory Service, Pretoria, Gauteng Province, South Africa
}

\begin{abstract}
The use of different concentrations of sodium hypochlorite solutions (placebo; $1 \%$ and $3.5 \%$ sodium hypochlorite solutions) and 2 water-storage containers (traditional plastic container and the improved CDC safe water-storage container) as interventions in 2 rural communities using different water sources (improved vs. unimproved) was evaluated over a period of 4 months. Standard methods were used to determine the presence of indicator organisms (total coliforms, faecal coliforms, Escherichia coli, faecal enterococci, Clostridium perfringens, male-specific F-RNA and somatic coliphages) in the water samples. The results indicated that the $1 \%$ and the $3.5 \%$ sodium hypochlorite solutions effectively reduced the numbers of indicator microorganisms to undetectable counts in both types of water-storage containers. However, no statistical differences were seen between the 2 types of water-storage containers in the numbers of indicator microorganisms present in the stored water with the addition of a placebo sodium hypochlorite solution. Compliance of households with the use of the sodium hypochlorite intervention ranged between $60 \%$ and $100 \%$. A household questionnaire survey indicated an urgent need for education concerning the risk of waterborne diseases, the proper use of safe household water-storage devices and water treatment processes and improvement of hygiene and sanitation practices in these rural households.
\end{abstract}

Keywords: rural households, safe water-storage container, sodium hypochlorite solution, South Africa, stored drinking water

\section{Introduction}

An estimated 1.2 bn. people worldwide do not have access to safe drinking water (WHO, 2002a; WHO, 2002b). Almost $2.2 \mathrm{~m}$. children under the age of 5 years die each year in developing countries due to diarrhoeal diseases associated with faecally contaminated water (WHO, 2002a). The main reason for these mortality rates is the absence of water-treatment infrastructures, which leaves rural communities with no other choice than to collect water for domestic purposes from untreated sources such as rivers, boreholes and springs (Sobsey, 2002). In addition, the water-storage containers used in these rural households are often not cleaned and are exposed to faecal contamination due to children who put their hands into the water, unhygienic handling of the water-storage containers, the use of dirty utensils to withdraw water, dust, animals, birds and various types of insects (Mintz et al., 1995; Reiff et al., 1996; CDC, 2001; WHO, 2002a).

Several studies carried out in developing communities to improve the microbiological quality of stored household drinking water, have reported on the effectiveness of treatments such as boiling, heating, sedimentation, filtration, exposure to ultraviolet radiation from sunlight and disinfection with sodium hypochlorite solutions (Gilman and Skillicorn, 1985; Mintz et al., 1995; Conroy et al., 1996; CDC, 2001; Sobsey,

\footnotetext{
* To whom all correspondence should be addressed.

営 +2715 962 8256; fax: +2715 5162561 ;

e-mail: natasha.potgieter@univen.ac.za

Received 12 November 2008; accepted in revised form 27 May 2009.
}

2002; Clasen et al., 2006). Studies which have investigated the shapes and sizes of household water-storage containers showed that the geometric design of household water-storage containers played an important role in ensuring that the stored drinking water does not become contaminated by external factors such as dirty hands and utensils (Patel and Isaacson, 1989; Sutton and Mubiana, 1989; Sobsey, 2002). The United States Centres for Disease Control and Prevention (CDC) and the Pan American Health Organisation (PAHO) have taken the results from all of these studies and designed a $20 \ell$ household water-storage container containing a valved spigot, a handle and a mediumsize opening to reduce the risk of external contamination of the water during water-storage (Mintz et al., 1995; Reiff et al., 1996; CDC, 2001; Sobsey, 2002).

The CDC safe water-storage container together with the addition of a sodium hypochlorite solution has been evaluated in several communities in developing countries (Macy and Quick, 1998; Semenza et al., 1998; CDC, 2001; Makhutsa et al, 2001; Sobsey, 2002; Sobsey et al., 2003; Lule et al., 2006; Shestrah et al., 2006). The first study to use the CDC safe water-storage container was carried out in Bolivia (Quick et al., 1996). In this study, 3 study groups were used: one group received the CDC safe water-storage container together with a sodium hypochlorite solution; one group received the CDC safe water-storage container without a sodium hypochlorite solution and one group used their traditional household water-storage container without a sodium hypochlorite solution. Results from this study showed that the stored water of the households who used the CDC safe water-storage container and a sodium hypochlorite solution had no faecal coliform and Escherichia coli (E. coli) counts, 
compared to $E$. coli counts ranging between 10 and $100 \mathrm{cfu} \cdot 100$ $\mathrm{m} \ell^{-1}$ in the households which used their traditional water-storage containers and the households which only received the CDC safe water-storage container (Quick et al., 1996).

Three years later another study was carried out in Bolivia using the CDC safe water-storage container together with a locally produced sodium hypochlorite solution. The aim of this study was to reduce the incidence of diarrhoeal disease (Quick et al., 1999). Two peri-urban communities in Bolivia using groundwater from uncovered shallow wells (hand-dug wells), covered wells equipped with a hand-pump, and a household tap from neighbouring communities were selected. The results from this intervention indicated that the water of most intervention households had no E. coli bacteria and contained detectable levels of free chlorine residual, while the water from households in the control group had counts of $E$. coli bacteria in excess of 1000 $\mathrm{cfu} \cdot 100 \mathrm{~m}^{-1}$ and contained no detectable free chlorine residual levels (Quick et al., 1999). This study further showed that households with the CDC safe water-storage container and sodium hypochlorite solution had fewer episodes of diarrhoea compared to households without the interventions (Quick et al., 1999).

On the African continent, studies with the CDC safe waterstorage container and sodium hypochlorite solutions have been carried out in Guinea-Bisseau (Daniels et al., 1999), Madagascar (Mong et al., 2001), Zambia (Quick et al., 2002), Kenya (Makutsa et al., 2001; Garett et al., 2008) and Uganda (Lule et al., 2005; Shestrah et al., 2006). In other developing countries, the CDC safe water-storage container intervention with sodium hypochlorite has been carried out in Uzbekistan (Semenza et al., 1998), Pakistan (Luby et al., 2001), Guatamala (Sobel et al., 1998), Bolivia (Quick et al., 1996; Quick et al., 1999; Sobsey et al., 2003) and Bangladesh (Sobsey et al., 2003). All of these studies have shown an improvement in the microbiological quality of the water when the $\mathrm{CDC}$ safe water-storage container and a sodium hypochlorite solution was used as a combined intervention strategy (Sobsey, 2002; Sobsey et al., 2003; Clasen et al., 2006).

To date, no investigation has been conducted into the introduction of the CDC safe water-storage container in rural communities of South Africa, especially in impoverished households such as those found in the Vhembe region of the Limpopo Province and the impact of disinfection practices such as chlorination of stored water supplies in these households has not been established either. The South African Department of Health $(\mathrm{DoH})$ recommends the addition of a $5 \mathrm{~m} \ell$ volume of a stabilised $3.5 \%$ sodium hypochlorite solution to $20 \ell$ of water for the treatment of drinking water $(\mathrm{DoH}$, water treatment pamphlets). However, the majority of people in rural communities do not treat their drinking water. Only during disease outbreaks such as cholera, will these rural communities start using the sodium hypochlorite solution as specified by the $\mathrm{DOH}$. The aim of this study was therefore to improve the microbiological quality of drinking water in rural households through the implementation of intervention strategies, which included the use of an improved household water-storage container (CDC safe water-storage container) and the addition of either a $1 \%$ or a $3.5 \%$ sodium hypochlorite solution.

\section{Materials and methods}

\section{Informed consent}

Ethical clearance to conduct this study was obtained from the ethics committees of the Department of Health, Polokwane, Limpopo Province, Republic of South Africa (RSA) and the
University of Pretoria, Gauteng Province, RSA. In each study household, the head of the household was asked to sign a written informed-consent document.

\section{Study sites}

Two rural villages in the Vhembe region were included in this study. In Village 1 the main water source was communal taps (improved water source) with untreated water, pumped directly from a borehole into a large open reservoir. In Village 2 the main water source was the Sambandou River (unimproved water source), which was also used for livestock watering, washing of clothes and recreational activities.

\section{Administration of household questionnaire}

A comprehensive questionnaire was administered to randomly selected households in one of the local dialects (Tshivenda or Xitsonga) by 2 postgraduate students from the University of Venda, Thohoyandou, RSA. Data were collected from each study household on water collection, water-storage practices and sanitation conditions in the household.

\section{Sodium hypochlorite and water-storage container interventions}

In each village 60 households were selected at random and then randomised into control and intervention groups. A group meeting was held with the selected households in each village before the study commenced to explain the purpose of the study. The actual concentration of the sodium hypochlorite solution to be added was not known to the selected households and they were informed during the group meeting that varying concentrations of sodium hypochlorite were going to be evaluated and they should be aware that different concentrations would have different smells, e.g. strong to weak. The intervention study was conducted over a 4 -month period. The treatment combinations of the intervention trial are presented in Table 1. The traditional $20 \ell$ water-storage container (called a 'tshigubu' with a capacity of $20 \ell$ ) was compared to the improved $20 \ell$ CDC safe water-storage container, with the addition of a placebo, $1 \%$ or $3.5 \%$ sodium hypochlorite solution. Each of the households in intervention Groups III, IV and $\mathrm{V}$ (Table 1) in each village received $2 \mathrm{CDC}$ safe water-storage containers to replace their traditional household water-storage containers. These households were visited individually and given clear instructions concerning the proper use and cleaning of the CDC safe water-storage container.

In addition, each household was shown the correct procedure to add the sodium hypochlorite solution to the water in the water-storage containers. Every $3^{\text {rd }}$ week, each study household was given a freshly prepared bottle of sodium hypochlorite solution. The placebo, $1 \%$ and $3.5 \%$ sodium hypochlorite solutions were all distributed in similar bottles and given to the households at the same time. Using a teaspoon as measuring device, all study households were instructed to add $5 \mathrm{ml}$ of provided sodium hypochlorite solution to the water in the water-storage container. The chosen volume of $5 \mathrm{~m} \ell$ is the standard recommended dosage stipulated by the Department of Health in South Africa for the 3.5\% sodium hypochlorite solution. Laboratory studies were performed to determine the chlorine demand curve for the $1 \%$ sodium hypochlorite solution with water from both sources. The results of repeated experiments have shown that $5 \mathrm{~m} \ell$ of the $1 \%$ sodium hypochlorite 


\begin{tabular}{|c|c|c|}
\hline \multicolumn{3}{|c|}{$\begin{array}{c}\text { TABLE } 1 \\
\begin{array}{c}\text { Summary of the intervention trial carried out in each of } 2 \text { rural villages in the Vhembe region of the Limpopo } \\
\text { Province, South Africa }\end{array}\end{array}$} \\
\hline Study group & Description of each group & $\begin{array}{l}\text { No. of HHs } \\
\text { per group }\end{array}$ \\
\hline Control I & Traditional household container with $5 \mathrm{~m} \ell$ placebo sodium hypochlorite solution & $10 \mathrm{HHs}$ \\
\hline Intervention I & $\begin{array}{l}\text { Traditional household container plus the addition of } 5 \mathrm{~m} \ell \text { of a stabilised } 3.5 \% \\
\text { sodium hypochlorite solution }\end{array}$ & $10 \mathrm{HHs}$ \\
\hline Intervention II & $\begin{array}{l}\text { Traditional household container plus the addition of a pre-determined volume of a } \\
\text { stabilised } 1.0 \% \text { sodium hypochlorite solution }\end{array}$ & $10 \mathrm{HHs}$ \\
\hline Intervention III & CDC safe-water-storage container with $5 \mathrm{~m} \ell$ placebo sodium hypochlorite solution & $10 \mathrm{HHs}$ \\
\hline Intervention IV & $\begin{array}{l}\text { CDC safe-water-storage container plus the addition of } 5 \mathrm{~m} \ell \text { of a stabilised } 3.5 \% \\
\text { sodium hypochlorite solution }\end{array}$ & $10 \mathrm{HHs}$ \\
\hline Intervention $\mathrm{V}$ & $\begin{array}{l}\text { CDC safe-water-storage container plus the addition of a pre-determined volume of } \\
\text { a stabilised } 1.0 \% \text { sodium hypochlorite solution }\end{array}$ & $10 \mathrm{HHs}$ \\
\hline \multicolumn{2}{|c|}{ Total number of households per village } & $60 \mathrm{HHs}$ \\
\hline
\end{tabular}

HHs $=$ households $\quad$ No. $=$ number $\quad$ Placebo sodium hypochlorite solution $=$ distilled water

solution gave a free chlorine concentration in the region of 0.5 to $1.5 \mathrm{mg} \cdot \ell^{-1}$ after $60 \mathrm{~min}$ as stipulated by the CDC. To be consistent, households who received the placebo sodium hypochlorite solution were advised to add $5 \mathrm{~m} \ell$ of their sodium hypochlorite solution to the water-storage containers.

\section{Water sample collection}

Drinking water samples were collected once a month for 4 months, both from the household water-storage containers and from the respective water sources. Aseptic techniques were used to collect $2 \ell$ water samples in sterile Nalgene (Merck, Darmstadt, Germany) collection bottles for microbiological analyses. The water-storage containers ( $25 \ell$ and smaller) were shaken before a sample was taken. If the water-storage containers were larger than $25 \ell$, the water sample was taken from the top of the container. During collection of communal tap water samples in Village 1, the water from the tap was allowed to run for $1 \mathrm{~min}$ before a sample was taken. During collection of river water samples in Village 2, care was taken to collect samples at the exact sites used by the study households as their collection points for domestic purposes. All samples were transported on ice to the laboratory and processed within $8 \mathrm{~h}$.

\section{Physicochemical analyses of water samples}

The temperature and turbidity of each water sample were determined on site using a Silberbrand laboratory thermometer (Merck, Darmstadt, Germany) and a portable HI93703 microprocessor turbidity meter (HANNA Instruments, Germany). Free chlorine residuals in each water sample were determined using the N, N-diethyl-phenylenediamine (DPD) colorimetric method according to the manufacturer's specifications (Merck, Darmstadt, Germany).

\section{Microbiological analyses of water samples}

Standard methods were employed for the detection of bacterial indicator organisms (Standard Methods, 1995). The PresenceAbsence Test to detect somatic and male-specific F-RNA bacteriophages was conducted according to methods published by the International Standardisation Organisation (ISO) (ISO,

1995; ISO, 2000). The Presence-Absence Test was used instead of the Double Agar Layer Test because a larger volume of the water samples could be analysed.

Selective media were used and prepared in $90 \mathrm{~mm}$ Petri dishes (Merck, Darmstadt, Germany) according to the manufacturer's instructions. Plate count agar (Difco Laboratories, Detroit, MI, USA) was used for the enumeration of heterotrophic microorganisms. The enumeration of total coliform bacteria was conducted on mEndo agar (Difco Laboratories, Detroit, MI, USA). Faecal coliform bacteria were enumerated on $\mathrm{mFc}$ agar (Difco Laboratories, Detroit, MI, USA). Faecal enterococci bacteria were enumerated on mEnterococcus agar (Difco Laboratories, Detroit, MI, USA). Nutrient-MUG (4-methyl-umbelliferyl- $\beta$-D-glucuronidase) agar (Difco Laboratories, Detroit, MI, USA) was used for the enumeration of $E$. coli. Clostridium perfringens OPSP agar with supplements A and B (Oxoid Ltd., Basingstoke, Hampshire, England) was used for the enumeration of Clostridium perfringens (C. perfringens) vegetative cells and spores.

\section{Enumeration of heterotrophic microorganisms in the water samples}

The number of heterotrophic counts was determined as colonyforming units per millilitre (cfu $\left.\cdot \mathrm{m}^{-1}\right)$ using the pour plate method (Standard Methods, 1995). Briefly, tenfold serial dilutions of each water sample were prepared in sterile distilled water. One $\mathrm{m} \ell$ of each dilution was added to $9 \mathrm{~m} \ell$ plate count agar that was kept in sterile $16 \mathrm{~mm}$ test tubes (Adcock Ingram Pty Ltd., Johannesburg, South Africa) at $55^{\circ} \mathrm{C}$ in a water bath. The test tubes were vortexed to mix the water sample and the agar and poured into sterile $90 \mathrm{~mm}$ Petri dishes (Merck, Darmstadt, Germany). After solidification of the agar, the plates were incubated under aerobic conditions at $37^{\circ} \mathrm{C}$ for $48 \mathrm{~h}$.

\section{Enumeration of coliforms, faecal enterococci and Clostridium perfringens in the water samples}

Water samples were assessed in duplicate for the presence of total coliforms, faecal coliforms, faecal enterococci and C. perfringens using the membrane filtration technique (Standard Methods, 1995). Sterile filtration membranes $(0.45 \mu \mathrm{m}$ pore size, $47 \mathrm{~mm}$ diameter) (Millipore, Johannesburg, South Africa) were prepared by passing $10 \mathrm{~m} \ell$ volumes of each water 
sample through the membranes using a vacuum pump and placing the membranes on the respective agar plates. Counts for each indicator organism were reported as colony forming units per $100 \mathrm{~m} \ell\left(\mathrm{cfu} \cdot 100 \mathrm{~m}^{-1}\right)$.

Total coliform plates were incubated aerobically at $37^{\circ} \mathrm{C}$ for $24 \mathrm{~h}$ and metallic-green colonies were counted. Faecal coliform plates were incubated aerobically at $44.5^{\circ} \mathrm{C}$ for $24 \mathrm{~h}$ and dark-blue colonies were counted. Faecal enterococci plates were incubated aerobically at $37^{\circ} \mathrm{C}$ for $48 \mathrm{~h}$ and pink colonies were counted. Clostridium perfringens plates were incubated in micro-aerophillic conditions at $37^{\circ} \mathrm{C}$ for $24 \mathrm{~h}$ using Anaerogen sachets (Oxoid Ltd., Basingstoke, Hampshire, England). Dark-brown to black colonies (both vegetative cells and spores) were counted.

\section{Enumeration of Escherichia coli in the water samples}

Membranes from the $\mathrm{mFc}$ agar plates containing faecal coliform bacteria were removed and placed directly onto NutrientMUG agar plates and incubated aerobically at $37^{\circ} \mathrm{C}$ for $24 \mathrm{~h}$. Plates were removed from the incubator and observed under a $366 \mathrm{~nm}$ ultraviolet light source (Merck, Darmstadt, Germany). Fluorescent colonies were counted as presumptive E. coli bacteria and the counts expressed as cfu $100 \mathrm{~m} \ell^{-1}$. Each presumptive E. coli colony was confirmed using Gram staining and indole tests with Kovac's reagent (Merck, Darmstadt, Germany) according to the techniques described by Mac Faddin (1980). All Gram -negative, indole-positive colonies were recorded as E. coli isolates (Mac Faddin, 1980).

\section{Presence-Absence Tests for the detection of somatic and male-specific F-RNA bacteriophages in the water samples}

The Presence-Absence Test was carried out following a procedure described by Uys (1999). Escherichia coli strain WG5 (ISO, 2000) and Salmonella typhimurium strain WG49 (ISO, 1995) were respectively used as bacterial hosts to isolate somatic and male specific F-RNA bacteriophages from the water samples. Each water sample was mixed to have a homogenous suspension and $500 \mathrm{~m} \ell$ was poured into a sterile plastic $1 \ell$ water collection bottle to which $5 \mathrm{~g}$ Trypticase Peptone (Difco Laboratories, Detroit, MI, USA), $0.5 \mathrm{~g}$ Yeast Extract (Difco Laboratories, Detroit, MI, USA), 4 g Sodium Chloride (Merck, Darmstadt, Germany) and $5 \mathrm{m \ell}$ of a calciumglucose solution were added. The Calcium-Glucose solution was prepared as follows: $3 \mathrm{~g}$ Calcium-Chloride $\left(\mathrm{CaCl}_{2} \cdot 2 \mathrm{H}_{2} \mathrm{O}\right)$ (Merck, Darmstadt, Germany) and $10 \mathrm{~g}$ Glucose (Merck, Darmstadt, Germany) were dissolved in $100 \mathrm{~m} \ell$ distilled water and filter sterilised using a $0.22 \mu \mathrm{m}$ syringe filter (Merck, Darmstadt, Germany). Host cultures were prepared according to ISO procedures (ISO, 1995; ISO, 2000). One m $\ell$ of the specific host culture was added to each of the water samples and incubated at $37^{\circ} \mathrm{C}$ for $24 \mathrm{~h}$. The presence of either somatic or F-RNA bacteriophages was determined by spotting $5 \mu \ell$ from each Presence-Absence water sample onto a pre-prepared lawn of host bacteria in $90 \mathrm{~mm}$ Petri dishes (Merck, Darmstadt, Germany) (Uys, 1999). The plates were incubated at $37^{\circ} \mathrm{C}$ for $24 \mathrm{~h}$ and zones of cell lysis (plaques) were considered positive and reported as 'present' for each water sample (Uys, 1999).

\section{Data analyses}

The Stata Release 8.0 statistical software package (Quantec,
RSA) was used to clean and edit the data, find summary statistics for each parameter and do comparative analyses. All parameters in the household questionnaires were of a categorical nature describing certain water and sanitation practices at the household level. Results (counts) for the water collections from the water sources and the household water-storage containers (as outlined in Table 1) were summarised for each water source and household group, using the geometric mean and a corresponding $95 \%$ confidence interval. At source level, i.e. tap or river, villages were compared using Students two-sample t-test. Within each village, sodium hypochlorite concentration and water-storage containers was compared using a two-way analysis of variance (ANOVA) followed by pair-wise comparisons using the Bonferromi adjustment. For indicator organisms, logarithmic transformed data were analysed. Exposure variables, i.e. hand-washing etc., were assessed with the incidence rate ratio (IRR) following a Poisson regression analysis. Testing was done at the 0.05 level of significance.

\section{Results and discussion}

The intervention households using the $1 \%$ and the $3.5 \%$ sodium hypochlorite solutions had zero counts for all indicator microorganisms in the water samples taken from both container types during the formal intervention trial. This indicated that both the $1 \%$ and $3.5 \%$ sodium hypochlorite solutions were effective home based treatments. Therefore, all physicochemical and microbiological results discussed will be from results on counts obtained for the traditional and CDC safe waterstorage containers in households receiving the placebo sodium hypochlorite solution.

\section{Turbidity (Table 2)}

Turbidity measurements give an indication of the concentration of suspended clay, silt, organic matter, inorganic matter, plankton and other microscopic organisms in a water source (DWAF, 1996). Both water sources and water-storage containers in both villages had turbidity values which exceeded the recommended South African guideline value of 0.1 NTU for turbidity (SABS, 2001). High turbidity values are associated with the survival of microorganisms due to association of the microorganisms with particulate matter in the water (DWAF, 1996). A significant difference $(\mathrm{P}<0.001)$ was observed in the turbidity values between the 2 types of water sources which suggested that the river water had more nutrients and particulate matter, which could have assisted in the survival and transmission of waterborne diseases due to the association between microorganisms and particulate matter (DWAF, 1996). In Village 1, no statistical difference $(\mathrm{P}>0.5)$ in the turbidity values from the communal tap water source, the traditional water-storage containers and the CDC safe water-storage containers was seen. Likewise, no statistical difference $(\mathrm{P}>0.05)$ was seen between the turbidity measurements of the 2 types of water-storage containers. In Village 2, a significant statistical difference between the turbidity values from the river water source and the traditional water-storage containers $(\mathrm{P}=0.008)$ and between the river water source and the $\mathrm{CDC}$ safe water-storage container $(\mathrm{P}<0.001)$ with river water was observed. The lower turbidity measurements in the water-storage containers could be due to settlement of particulate matter in the containers during water storage especially if the water-storage containers were larger than $25 \ell$. In general, no statistical differences $(\mathrm{P}=0.350)$ were observed between the turbidity values from the traditional and 


\begin{tabular}{|c|c|c|c|c|c|c|}
\hline \multicolumn{7}{|c|}{$\begin{array}{c}\text { TABLE } 2 \\
\text { Summary of the physicochemical parameters (95\% confidence intervals) of the water sources and the } \\
\text { traditional and improved household water-storage containers of } 2 \text { rural villages in the Vhembe region of } \\
\text { the Limpopo Province, South Africa }\end{array}$} \\
\hline \multirow[b]{2}{*}{ Physical parameters } & \multicolumn{3}{|c|}{\begin{tabular}{|l} 
Village 1 using tap water \\
\end{tabular}} & \multicolumn{3}{|c|}{$\begin{array}{l}\text { Village } 2 \text { using river water } \\
\end{array}$} \\
\hline & \begin{tabular}{|l|}
$\begin{array}{l}\text { Communal tap- } \\
\text { water sources }\end{array}$ \\
\end{tabular} & $\begin{array}{c}\text { Traditional } \\
\text { water-storage } \\
\text { container }\end{array}$ & $\begin{array}{c}\text { CDC safe } \\
\text { water-storage } \\
\text { container }\end{array}$ & $\begin{array}{l}\text { River-water } \\
\text { source }\end{array}$ & $\begin{array}{c}\text { Traditional } \\
\text { water-storage } \\
\text { container }\end{array}$ & $\begin{array}{c}\text { Improved CDC } \\
\text { water-storage } \\
\text { container }\end{array}$ \\
\hline pH & $\begin{array}{c}7.0 \\
(7.0 ; 7.1) \\
\end{array}$ & $\begin{array}{c}7.3 \\
(7.0 ; 7.8) \\
\end{array}$ & $\begin{array}{c}7.3 \\
(7.0 ; 7.8) \\
\end{array}$ & $\begin{array}{c}7.2 \\
(6.8 ; 7.7)\end{array}$ & $\begin{array}{c}7.0 \\
(6.9 ; 7.2)\end{array}$ & $\begin{array}{c}7.4 \\
(6.7 ; 7.6)\end{array}$ \\
\hline Temperature $\left({ }^{\circ} \mathrm{C}\right)$ & $\begin{array}{c}19.4 \\
(18.6 ; 20.2)\end{array}$ & $\begin{array}{c}20.2 \\
(19.2 ; 21.3)\end{array}$ & $\begin{array}{c}19.4 \\
(18.6 ; 20.2)\end{array}$ & $\begin{array}{c}19.3 \\
(15.6 ; 22.9)\end{array}$ & $\begin{array}{c}19.3 \\
(18.6 ; 19.9)\end{array}$ & $\begin{array}{c}19.7 \\
(18.7 ; 19.9)\end{array}$ \\
\hline Turbidity (NTU) & $\begin{array}{c}0.6 \\
(0.3 ; 1.0)\end{array}$ & $\begin{array}{c}0.6 \\
(0.1 ; 1.1)\end{array}$ & $\begin{array}{c}0.9 \\
(0.2 ; 1.5)\end{array}$ & $\begin{array}{c}5.9 \\
(4.1 ; 7.7)\end{array}$ & $\begin{array}{c}4.2 \\
(3.0 ; 5.3)\end{array}$ & $\begin{array}{c}3.5 \\
(2.4 ; 4.6)\end{array}$ \\
\hline
\end{tabular}

improved CDC water-storage containers in all study households receiving the placebo sodium hypochlorite solution.

\section{Temperature (Table 2)}

Several studies have shown that temperature plays an important role in the survival of microorganisms and the effectiveness of a disinfectant. Atkin et al, (1971) and Sattar (1981) have shown that viruses have a tendency to survive longer in groundwater sources than in surface water at similar temperatures. Carlsson (2003) stated that an increase in water temperatures can result in higher rates of inactivation of microorganisms in water samples. The South African recommended guideline values for water temperature ranged between 18 to $24^{\circ} \mathrm{C}$ (DWAF, 1996). The temperatures for all water samples in this study fell well within this range. During this study very few fluctuations in the temperature measurements in the sources and in both the traditional and CDC safe water-storage containers were seen, which indicated that the microorganisms present in the sources and the containers were not exposed to temperature extremes which could have affected their survival and growth (Allwood et al., 2003; Skraber et al., 2004). The temperature measurements indicated no significant difference $(\mathrm{P}=0.867)$ between the temperature values of the 2 types of water sources. In Village 1 no statistical difference $(\mathrm{P}>0.3)$ was found between the temperature values from the communal tap-water source, the traditional water-storage containers and the CDC safe water-storage containers. In addition, no significant difference $(\mathrm{P}=0.193)$ was seen in the temperature measurements between the 2 types of water-storage containers containing the tap water. In Village 2 , no statistical difference $(\mathrm{P}>0.5)$ was observed between the temperature values from the communal tap-water source, the traditional water-storage containers and the $\mathrm{CDC}$ safe water-storage containers containing the river water. In general, no statistical differences $(\mathrm{P}=0.193)$ were observed between the temperature values from the traditional and improved CDC water-storage containers in all study households receiving the placebo sodium hypochlorite solution.

\section{pH (Table 2)}

The $\mathrm{pH}$ of a water sample, especially with regards to disinfection of microorganisms could play an important role. Various studies have shown that bacteriophages and viruses are affected differently in their susceptibility to chlorine disinfection due to changes in $\mathrm{pH}$ and temperatures of water sources (Engelbrecht et al., 1980; Schaper et al., 2002). A study by Vaughn et al. (1986) showed that viruses are more readily inactivated by chlorine when the water has a $\mathrm{pH}$ level of 6 compared to when the water sample had a $\mathrm{pH}$ level of 8 . In this study the statistical analyses of the $\mathrm{pH}$ measurements indicated no significant difference $(\mathrm{P}=0.783)$ between the $\mathrm{pH}$ values of the 2 types of water sources. The $\mathrm{pH}$ values for tap water and river water fell within the South African water quality $\mathrm{pH}$ guideline range for domestic use of 6.0 to 9.0 (DWAF, 1996). In Village 1 no statistical differences $(\mathrm{P}>0.35)$ were found between the $\mathrm{pH}$ values from the communal tap-water source, the traditional water-storage containers and the $\mathrm{CDC}$ safe water-storage containers. In addition, no significant differences $(\mathrm{P}=0.483)$ were seen in the temperature measurements between the 2 types of water-storage containers containing tap water. In Village 2, no statistical difference $(\mathrm{P}=0.423)$ was found between the $\mathrm{pH}$ values from the communal tap water source, the traditional waterstorage containers and the CDC safe water-storage containers. In general, no statistical differences $(\mathrm{P}=0.350)$ were observed between the $\mathrm{pH}$ values from the traditional and improved CDC water-storage containers in all study households receiving the placebo sodium hypochlorite solution.

\section{Heterotrophic bacteria (Tables 3 and 4)}

Heterotrophic plate counts indicated the general microbiological quality of the water samples and mostly included microorganisms that required organic carbon for growth (DWAF, 1996; WHO, 2002b). Generally heterotrophic microorganisms are considered to be harmless. However, various studies have indicated that some heterotrophic microorganisms such as Aeromona spp., Klebsiella pneumoniae, Enterococcus spp., Flavobacterium spp., Bacillus spp. and Enterobacter spp. might be opportunistic pathogens (Payment et al., 1991; WHO, 2002b; Bartram et al., 2003). These opportunistic pathogens have been associated with diseases in immunocompromised individuals, infants and the elderly during exposure to or consumption of contaminated water (Payment et al., 1991; Bartram et al., 2003). The heterotrophic plate counts in both the water sources and the traditional and CDC safe water-storage container water samples exceeded the South African recommended guideline value of $100 \mathrm{cfu} \cdot \mathrm{m} \ell^{-1}$ (SABS, 2001). No statistical difference $(\mathrm{P}=0.272)$ could be seen between the heterotrophic bacterial counts of the river- and tap-water sources. Heterotrophic microorganisms are found as natural inhabitants of water and soil environments and might have been present in the communal tap water due to biofilms inside the reservoir and pipe distribution systems or because of animal- and human activities inside 


\begin{tabular}{|c|c|c|c|c|c|c|}
\hline \multicolumn{7}{|c|}{$\begin{array}{c}\text { TABLE } 3 \\
\text { Mean values (95\% confidence intervals) for microbiological indicators of water samples from communal } \\
\text { tap-water sources and the stored household water in traditional and improved CDC safe water-storage } \\
\text { containers used by households together with the placebo sodium hypochlorite solution from Village } 1 \text { in } \\
\text { the Vhembe region of the Limpopo Province, South Africa }\end{array}$} \\
\hline $\begin{array}{l}\text { Water source and } \\
\text { container type }\end{array}$ & $\begin{array}{c}\text { Heterotrophic } \\
\text { bacteria } \\
\left(\mathrm{cfu} \cdot 1 \mathrm{~m} \mathrm{\ell}^{-1}\right)\end{array}$ & $\begin{array}{c}\text { Total } \\
\text { coliforms } \\
\left.\text { (cfu-100 } \ell^{-1}\right)\end{array}$ & $\begin{array}{c}\text { Faecal } \\
\text { coliforms } \\
\left.\text { (cfu-100 m } \ell^{-1}\right)\end{array}$ & $\begin{array}{c}\text { Escherichia } \\
\text { coli } \\
\left(\mathrm{cfu} \cdot 100 \mathrm{me}^{-1}\right)\end{array}$ & 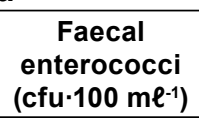 & $\begin{array}{c}\text { Clostridium } \\
\text { perfringens } \\
\text { (cfu } \cdot 100 \cdot \mathrm{m}^{-1} \text { ) }\end{array}$ \\
\hline $\begin{array}{l}\text { Communal tap } \\
\text { source }\end{array}$ & $\begin{array}{c}1.6 \times 10^{6} \\
\left(6.6 \times 10^{5} ; 4.2 \times 10^{6}\right)\end{array}$ & $\begin{array}{c}360 \\
(247 ; 525)\end{array}$ & $\begin{array}{c}180 \\
(116 ; 277)\end{array}$ & $\begin{array}{c}84 \\
(54 ; 124)\end{array}$ & $\begin{array}{c}37 \\
(18 ; 72)\end{array}$ & $\begin{array}{c}34 \\
(14 ; 83)\end{array}$ \\
\hline $\begin{array}{l}\text { Traditional } \\
\text { containers }^{\star *}\end{array}$ & $\begin{array}{c}3.0 \times 10^{7} \\
\left(7.7 \times 10^{6} ; 1.2 \times 10^{8}\right)\end{array}$ & $\begin{array}{c}783 \\
(435 ; 1411)\end{array}$ & $\begin{array}{c}414 \\
(221 ; 775)\end{array}$ & $\begin{array}{c}115 \\
(77 ; 170)\end{array}$ & $\begin{array}{c}100 \\
(51 ; 197)\end{array}$ & $\begin{array}{c}98 \\
(69 ; 140)\end{array}$ \\
\hline $\begin{array}{l}\text { CDC safe water- } \\
\text { storage containers }\end{array}$ & $\begin{array}{c}1.7 \times 10^{7} \\
\left(5.0 \times 10^{6} ; 5.4 \times 10^{7}\right)\end{array}$ & $\begin{array}{c}944 \\
(638 ; 1390)\end{array}$ & $\begin{array}{c}578 \\
(409 ; 816)\end{array}$ & $\begin{array}{c}120 \\
(74 ; 196)\end{array}$ & $\begin{array}{c}105 \\
(47 ; 233)\end{array}$ & $\begin{array}{c}90 \\
(40 ; 199)\end{array}$ \\
\hline
\end{tabular}

\section{TABLE 4}

Mean values ( $95 \%$ confidence intervals) for microbiological indicators of water samples collected from communal tap-water sources and the stored household water in traditional and improved CDC safe water-storage containers used by households together with the placebo sodium hypochlorite solution from Village 2 in the Vhembe region of the Limpopo Province, South Africa

\begin{tabular}{|c|c|c|c|c|c|c|}
\hline $\begin{array}{l}\text { Water source and } \\
\text { container type }\end{array}$ & $\begin{array}{c}\text { Heterotrophic } \\
\text { bacteria } \\
\text { (cfu-1 me-1) }\end{array}$ & $\begin{array}{c}\text { Total } \\
\text { coliforms } \\
\left.\text { (cfu-100 m } \ell^{-1}\right) \\
\end{array}$ & 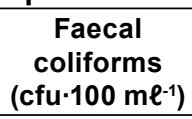 & $\begin{array}{c}\text { Escherichia } \\
\text { coli } \\
\left.\text { (cfu-100 m } \ell^{-1}\right)\end{array}$ & $\begin{array}{c}\text { Faecal } \\
\text { enterococci } \\
\left.\text { (cfu-100 } \mathrm{m}^{-1}\right) \\
\end{array}$ & $\begin{array}{c}\text { Clostridium } \\
\text { perfringens } \\
\left(\mathrm{cfu} \cdot 100 \cdot \mathrm{m} \mathrm{\ell}^{-1}\right)\end{array}$ \\
\hline River-water source * & $\begin{array}{c}2.1 \times 10^{6} \\
\left(1.1 \times 10^{5} ; 3.9 \times 10^{7}\right)\end{array}$ & $\begin{array}{c}844 \\
(691 ; 1032)\end{array}$ & $\begin{array}{c}538 \\
(328 ; 883)\end{array}$ & $\begin{array}{c}166 \\
(90 ; 306)\end{array}$ & $\begin{array}{c}154 \\
(42 ; 582)\end{array}$ & $\begin{array}{c}132 \\
(21 ; 807)\end{array}$ \\
\hline $\begin{array}{l}\text { Traditional contain- } \\
\text { ers }^{* *}\end{array}$ & $\begin{array}{c}5.3 \times 10^{6} \\
\left(5.5 \times 10^{5} ; 5.1 \times 10^{7}\right)\end{array}$ & \begin{tabular}{|c|}
1345 \\
$(1100 ; 1643)$
\end{tabular} & $\begin{array}{c}1025 \\
(784 ; 1341)\end{array}$ & $\begin{array}{c}413 \\
(279 ; 610)\end{array}$ & $\begin{array}{c}139 \\
(80 ; 241)\end{array}$ & $\begin{array}{c}170 \\
(106 ; 274)\end{array}$ \\
\hline $\begin{array}{l}\text { CDC safe water-stor- } \\
\text { age containers }{ }^{\star *}\end{array}$ & $\begin{array}{c}1.0 \times 10^{7} \\
\left(2.2 \times 10^{6} ; 4.8 \times 10^{7}\right)\end{array}$ & $\begin{array}{c}1380 \\
(1157 ; 1646)\end{array}$ & $\begin{array}{c}1090 \\
(855 ; 1389)\end{array}$ & $\begin{array}{c}343 \\
(215 ; 548)\end{array}$ & $\begin{array}{c}94 \\
(62 ; 142)\end{array}$ & $\begin{array}{c}125 \\
(95 ; 165)\end{array}$ \\
\hline
\end{tabular}

* $n=4$ sites on river $\quad * * n=10$ households

the river catchment (Bartram et al., 2003). In Village 1 no statistical difference was found between the tap water source and the traditional water-storage containers $(\mathrm{P}=0.359)$ or between the tap water source and the $\mathrm{CDC}$ safe water-storage containers $(\mathrm{P}=0.968)$. Likewise, no statistical difference $(\mathrm{P}=0.459)$ was found between the traditional water-storage containers and the $\mathrm{CDC}$ safe water-storage containers containing the tap water. In Village 2 no statistical difference was found between the river water source and the traditional water-storage containers $(\mathrm{P}=0.196)$ or between the river water source and the CDC safe water-storage containers $(\mathrm{P}=0.303)$. Likewise, no statistical difference $(\mathrm{P}=0.597)$ was found between the traditional waterstorage containers and the CDC safe water-storage containers containing the river water. In general, no statistical differences $(\mathrm{P}=0.974)$ were observed between the heterotrophic bacteria counts from the traditional and improved $\mathrm{CDC}$ water-storage containers in all study households receiving the placebo sodium hypochlorite solution. The slight increase in heterotrophic plate counts in both the traditional and the CDC safe water-storage containers could be ascribed to:

- Secondary contamination of the stored water

- Re-growth of some heterotrophic microorganisms

- Unhygienic water-handling practices (Nala et al., 2003).

Consequently, the high heterotrophic plate counts in the waterstorage containers indicated an increased health risk to people consuming the water, due to the fact that opportunistic pathogenic microorganisms such as Aeromona spp. and Pseudomonas spp., which have been associated with diseases such as diarrhoea, skin, eye and respiratory infections might be present (DWAF, 1996; Bartram et al., 2003).

\section{Total coliform bacteria counts (Tables 3 and 4)}

Total coliforms include bacteria of known faecal origin such as E. coli, bacteria such as Citrobacter spp. and Enterobacter spp. which may be found in faeces and the environment (WHO, 1996) and bacteria such as Serratia spp. which may replicate in water environments (WHO, 1996). Results indicated that both the water sources and the stored water in both types of water-storage containers in Village 1 and Village 2 exceeded the South African recommended guideline value of $10 \mathrm{cfu} \cdot 100$ $\mathrm{m} \ell^{-1}$ for total coliforms in water intended for domestic purposes (SABS, 2001). A statistical difference $(\mathrm{P}=0.004)$ could be seen between the total coliform bacterial counts of the riverand tap-water sources. The high total coliform counts in the water sources and especially in the water-storage containers increased the health risk associated with waterborne diseases such as gastroenteritis, dysentery, cholera, typhoid fever and salmonellosis which are caused by pathogenic organisms such as Salmonella spp., Shigella spp., Vibrio cholerae, Campylobacter jejuni, Campylobacter coli, Yersinia enterocolitica 
and pathogenic E. coli (DWAF, 1996). In Village 1, statistical differences was found between the tap water source and the traditional water-storage containers $(\mathrm{P}=0.02)$ and between the tap water source and the CDC safe water-storage containers $(\mathrm{P}=0.003)$. However, no statistical differences $(\mathrm{P}=0.557)$ were found between the traditional water-storage containers and the CDC safe water-storage containers containing tap water. In Village 2, statistical differences were found between the river water source and the traditional water-storage containers $(P=0.0005)$ and between the river water source and the $\mathrm{CDC}$ safe water-storage containers $(\mathrm{P}=0.0001)$. However, no statistical difference $(\mathrm{P}=0.829)$ was found between the traditional water-storage containers and the $\mathrm{CDC}$ safe water-storage containers containing river water. In general, no statistical difference $(\mathrm{P}=0.557)$ was observed between the total coliform bacteria counts from the traditional and improved CDC waterstorage containers in all study households receiving the placebo sodium hypochlorite solution. The increase in the total coliform counts in both the traditional and the CDC safe water-storage containers during water-storage at the point-of-use in both villages indicated secondary contamination due to unhygienic handling practices and inappropriate water-storage conditions (Jagals et al., 1999).

\section{Faecal coliform bacteria counts (Tables 3 and 4)}

Faecal coliform bacteria were used in this study to indicate the presence of potential pathogenic microorganisms that is transmitted through the faecal-oral route (DWAF, 1996). The faecal coliform counts in both the water sources and in both types of household water-storage containers exceeded the South African recommended guideline value of $0 \mathrm{cfu} \cdot 100$ $\mathrm{m} \ell^{-1}$ (SABS, 2001). A statistical difference $(\mathrm{P}=0.004)$ could be seen between the faecal coliform bacterial counts of the river- and tap-water sources. The high faecal coliform counts in the river water samples indicated that the river has been contaminated due to direct faecal contamination from warm-blooded animals/humans or it could have been due to sewage run-offs during rainy periods (WHO, 2002a). In Village 1, statistical differences were found between the tap water source and the traditional water-storage containers $(\mathrm{P}=0.012)$ and between the tap water source and the CDC safe water-storage containers $(\mathrm{P}=0.0001)$. However, no statistical difference $(\mathrm{P}=0.306)$ was found between the traditional water-storage containers and the CDC safe water-storage containers containing tap water. In Village 2, statistical differences were found between the river water source and the traditional water-storage containers $(\mathrm{P}=0.0004)$ and between the river water source and the $\mathrm{CDC}$ safe water-storage containers $(\mathrm{P}=0.0001)$. However, no statistical difference $(\mathrm{P}=0.708)$ was found between the traditional water-storage containers and the CDC safe water-storage containers containing river water. In general, no statistical differences $(\mathrm{P}=0.364)$ were observed between the faecal coliform bacteria counts from the traditional and improved CDC water-storage containers in all study households receiving the placebo sodium hypochlorite solution. The microbiological increase in water quality after collection, showed that secondary contamination either due to human or animal faecal matter, occurred because of unhygienic water-storage and handling practices at the point-ofuse (DWAF, 1996). This was in agreement with results from previous studies indicating the microbiological decrease in water quality after collection (Sobsey, 2002; Fewtrell et al., 2005).

\section{Eschericia coli bacteria counts (Tables 3 and 4)}

Escherichia coli is used as the preferred indicator of faecal pollution (Edberg et al., 2000). The South African guideline value for $E$. coli in water intended for domestic use is $0 \mathrm{cfu} \cdot 100$ $\mathrm{m}^{-1}$ (SABS, 2001). During this study the E. coli counts exceeded the recommended guideline value for both the water sources and the two types of water-storage containers. A statistical difference $(\mathrm{P}=0.010)$ could be seen between the $E$. coli bacterial counts of the river- and tap-water sources. This indicated that unimproved sources (river water) were more prone to faecal contamination than improved sources (communal taps) due to human and animal activities in the vicinity of the source. In Village 1, no statistical differences were found between the tap water source and the traditional water-storage containers $(\mathrm{P}=0.109)$ and between the tap water source and the $\mathrm{CDC}$ safe water-storage containers $(\mathrm{P}=0.131)$. Likewise, no statistical differences were found between the traditional waterstorage containers and the CDC safe water-storage containers $(\mathrm{P}=0.861)$ containing tap water. In Village 2 , statistical difference was found between the river water source and the traditional water-storage containers $(\mathrm{P}=0.0005)$ and between the river water source and the $\mathrm{CDC}$ safe water-storage containers $(\mathrm{P}=0.007)$. However, no statistical difference $(\mathrm{P}=0.501)$ was found between the traditional water-storage containers and the $\mathrm{CDC}$ safe water-storage containers containing river water. In general, no statistical differences $(\mathrm{P}=0.802)$ were observed between the $E$. coli counts from the traditional and improved $\mathrm{CDC}$ water-storage containers in all study households receiving the placebo sodium hypochlorite solution. Although E. coli is found in the faeces of humans and animals, pathogenic $E$. coli strains have virulence factors, which could be responsible for the cause of disease and therefore implicate a potential health risk to the consumers (Kuhnert et al., 2000).

\section{Faecal enterococci bacteria counts (Tables 3 and 4)}

Faecal enterococci counts in this study were used to indicate the presence of human faecal contamination in the water samples (SABS, 2001). The South African water quality guideline value for faecal enterococci in water intended for domestic use is $0 \mathrm{cfu} \cdot 100 \mathrm{~m}^{-1}$ (SABS, 2001). A statistical difference $(\mathrm{P}=0.001)$ could be seen between the faecal enterococci bacteria counts of the river- and tap-water sources. In Village 1 , statistical differences were found between the tap water source and the traditional water-storage containers $(\mathrm{P}<0.001)$ and between the tap water source and the CDC safe waterstorage containers $(\mathrm{P}<0.001)$. However, no statistical difference $(\mathrm{P}=0.917)$ was found between the traditional water-storage containers and the CDC safe water-storage containers containing tap water. The increase in the faecal enterococci counts in both types of water-storage containers in Village 1 households indicated secondary contamination through unhygienic practices during collection and water-storage at the point-of-use. In Village 2 households, the faecal enterococci counts were similar to those seen in the water source which indicated that the collected water was already contaminated. No statistical differences were found between the river water source and the traditional water-storage containers $(\mathrm{P}=0.597)$ while a significant reduction $(\mathrm{P}=0.0001)$ in the faecal enterococci counts for the CDC safe water-storage containers was observed. However, no statistical difference $(\mathrm{P}=0.216)$ was found between the traditional water-storage containers and the CDC safe water-storage containers containing river water. In general, 
TABLE 5

Presence-absence test analyses of source water (communal tap- and river water) and stored water (traditional and improved CDC safe water-storage containers), both using the placebo sodium hypochlorite solution in Village 1 and 2 in the Vhembe region of the Limpopo Province, South Africa

\begin{tabular}{|c|c|c|c|c|c|c|}
\hline \multirow[b]{2}{*}{$\begin{array}{l}\text { Bacteriophage } \\
\text { type }\end{array}$} & \multicolumn{3}{|c|}{ Village 1} & \multicolumn{3}{|c|}{ Village 2} \\
\hline & $\begin{array}{c}\text { Communal tap } \\
\text { sources } \\
\text { (n=16 taps) }\end{array}$ & $\begin{array}{c}\text { Traditional } \\
\text { water-storage } \\
\text { containers } \\
(\mathrm{n}=10 \mathrm{HH})\end{array}$ & $\begin{array}{c}\text { CDC safe } \\
\text { water-storage } \\
\text { containers } \\
(\mathrm{n}=10 \mathrm{HH})\end{array}$ & $\begin{array}{c}\text { River-water } \\
\text { source } \\
\text { ( } n=4 \text { sites) }\end{array}$ & $\begin{array}{c}\text { Traditional } \\
\text { water-storage } \\
\text { container } \\
(\mathrm{n}=10 \mathrm{HH})\end{array}$ & $\begin{array}{c}\text { CDC safe } \\
\text { water-storage } \\
\text { container } \\
(\mathrm{n}=10 \mathrm{HH})\end{array}$ \\
\hline Somatic & $\begin{array}{c}1 / 16 \\
(6.3 \%)\end{array}$ & $\begin{array}{c}9 / 10 \\
(90 \%)\end{array}$ & $\begin{array}{c}10 / 10 \\
(100 \%)\end{array}$ & $\begin{array}{c}4 / 4 \\
(100 \%)\end{array}$ & $\begin{array}{c}10 / 10 \\
(100 \%)\end{array}$ & $\begin{array}{c}10 / 10 \\
(100 \%)\end{array}$ \\
\hline Male-specific F-RNA & $\begin{array}{c}1 / 16 \\
(6.3 \%)\end{array}$ & $\begin{array}{c}8 / 10 \\
(80 \%)\end{array}$ & $\begin{array}{c}9 / 10 \\
(90 \%)\end{array}$ & $\begin{array}{c}4 / 4 \\
(100 \%)\end{array}$ & $\begin{array}{c}10 / 10 \\
(100 \%)\end{array}$ & $\begin{array}{c}10 / 10 \\
(100 \%)\end{array}$ \\
\hline
\end{tabular}

no statistical differences $(\mathrm{P}=0.532)$ were observed between the faecal enterococci bacteria counts from the traditional and improved CDC water-storage containers in all study households receiving the placebo sodium hypochlorite solution.

\section{Clostridium perfringens bacteria counts (Tables 3 and 4)}

Clostridium perfringens is associated with soil as well as with animal and human faeces and the spores could survive for long periods in the environment (Listle et al., 2004). A significant difference $(\mathrm{P}<0.001)$ could be seen between the $C$. perfringens counts of the river- and tap-water sources. The presence of $C$. perfringens in the water sources indicated that potential pathogenic viruses (e.g. Enteroviruses and Hepatitis A virus) and parasites (e.g. Giardia and Cryptosporidium) could have been present in the water. Diseases such as hepatitis, meningitis and gastroenteritis can be caused by these pathogens (Payment and Franco, 1993). In Village 1, statistical differences were found between the tap- water source and the traditional water-storage containers $(\mathrm{P}=0.0001)$ and between the tap-water source and the $\mathrm{CDC}$ safe water-storage containers $(\mathrm{P}=0.022)$. However, no statistical difference $(\mathrm{P}=0.829)$ was found between the traditional water-storage containers and the CDC safe water-storage containers containing tap water. In Village 2, no statistical differences were found between the river water source and the traditional water-storage containers $(\mathrm{P}=0.247)$ and between the river-water source and the $\mathrm{CDC}$ safe water-storage containers $(\mathrm{P}=0.684)$. Likewise, no statistical difference $(\mathrm{P}=0.216)$ was found between the traditional water-storage containers and the $\mathrm{CDC}$ safe water-storage containers containing river water. In general, no statistical significances $(\mathrm{P}=0.401)$ were observed between the $C$. perfringens bacteria counts from the traditional and improved CDC water-storage containers in all study households receiving the placebo sodium hypochlorite solution. The $C$. perfringens counts in this study suggested that the spores could have survived in sediments in the river and in the communal tap reservoir.

\section{Bacteriophage counts (Table 5)}

The direct detection of viruses in water samples would be preferred. However, viral isolation and detection methods are expensive, labour intensive and require skilled personnel. Therefore, indicator organisms such as C. perfringens, somatic and F-RNA bacteriophages were used to indicate the potential presence of pathogenic enteric viruses (Grabow et al., 1993; Leclerc et al., 2000). According to the South African guidelines, no somatic bacteriophage counts should be detected in a $10 \mathrm{~m} \ell$ water sample (SABS, 2001). The presence of both somatic and F-RNA bacteriophages in the water sources and the traditional and CDC safe water-storage containers in both villages, indicated the potential risk of the presence of human viruses such as Adenoviruses, Astroviruses, Caliciviruses, Enteroviruses, Hepatitis A virus and Rotaviruses which could have caused diseases such as hepatitis, myocarditis and gastroenteritis to consumers (Grabow et al., 1993). The increase in somatic and F-RNA bacteriophage prevalence in household water-storage containers of the households using communal tap water indicated secondary contamination after collection and during water-storage at the point-of-use possibly due to unhygienic practices.

\section{Compliance in households using the $1 \%$ and $3.5 \%$ sodium hypochlorite solutions (Table 6)}

During the intervention study, the presence of a free chlorine residual in both the traditional and the CDC safe containers in the households which used the $1 \%$ and $3.5 \%$ sodium hypochlorite solutions were measured to determine whether these households complied with the use of the sodium hypochlorite solutions. Village 1 households complied between $60 \%$ and $100 \%$ and gave two reasons for the low levels of compliance. The first reason was because the people believed tap water was microbiologically cleaner than river water (which they have been using before the introduction of communal taps) and therefore it was not necessary to treat the water. The second reason was that households using the $3.5 \%$ sodium hypochlorite solution did not like the taste of the sodium hypochlorite in the water, which could be due to the free chlorine residual of the $3.5 \%$ sodium hypochlorite water samples that ranged between 3.8 and $4.5 \mathrm{mg} \cdot \ell^{-1}$ after $60 \mathrm{~min}$. This free chlorine residual is more than the recommended level of $0.8 \mathrm{mg} \cdot \ell^{-1}$ (DWAF, 1996) which was only achieved after letting the water stand for $24 \mathrm{~h}$ and not $2 \mathrm{~h}$ as suggested by the DoH and DWAF. Freese and Nozaic (2004) have reported that high concentrations of chlorine in drinking water can lead to the formation of trihalomethanes (THMs) which have been associated with various types of cancers. Village 2 households complied between 90 and $100 \%$ and had no complaints about the taste of the sodium hypochlorite in the treated stored water. In general, the levels of compliance in households for both villages were in agreement with other studies (Quick et al., 1999; 2002; Reller et al., 2003; Crump et al., 2005). 


\begin{tabular}{|c|c|c|c|c|c|c|c|}
\hline \multicolumn{8}{|c|}{$\begin{array}{c}\text { TABLE } 6 \\
\text { Compliance by intervention households who used either a } 1 \% \text { or a } 3.5 \% \text { sodium hypochlorite solution as an } \\
\text { intervention together with their traditional water-storage containers or an improved CDC safe water-storage } \\
\text { container }\end{array}$} \\
\hline \multirow[t]{3}{*}{$\begin{array}{l}\text { Study } \\
\text { population }\end{array}$} & \multirow[t]{3}{*}{$\begin{array}{l}\text { Container } \\
\text { Type }\end{array}$} & \multirow{2}{*}{\multicolumn{2}{|c|}{$\begin{array}{c}\text { Round } 1 \\
\text { (at end of month 1) } \\
\begin{array}{c}\text { Sodium hypochlorite } \\
\text { intervention }\end{array}\end{array}$}} & \multirow{2}{*}{\multicolumn{2}{|c|}{$\begin{array}{c}\text { Round } 2 \\
\text { (at end of month 2) } \\
\begin{array}{c}\text { Sodium hypochlorite } \\
\text { intervention }\end{array}\end{array}$}} & \multirow{2}{*}{\multicolumn{2}{|c|}{$\begin{array}{c}\text { Round } 3 \\
\text { (at end of month 3) } \\
\begin{array}{c}\text { Sodium hypochlorite } \\
\text { intervention }\end{array}\end{array}$}} \\
\hline & & & & & & & \\
\hline & & $1 \%$ & $3.5 \%$ & $1 \%$ & $3.5 \%$ & $1 \%$ & $3.5 \%$ \\
\hline \multirow{2}{*}{$\begin{array}{l}\text { Village } 1 \text { households } \\
\text { using communal taps } \\
\text { as primary water } \\
\text { source }\end{array}$} & Traditional & $\begin{array}{c}80 \% \\
(\mathrm{n}=10 \mathrm{HH})\end{array}$ & $\begin{array}{c}70 \% \\
(\mathrm{n}=10 \mathrm{HH})\end{array}$ & $\begin{array}{c}70 \% \\
(\mathrm{n}=10 \mathrm{HH})\end{array}$ & $\begin{array}{c}70 \% \\
(\mathrm{n}=10 \mathrm{HH})\end{array}$ & $\begin{array}{c}70 \% \\
(\mathrm{n}=10 \mathrm{HH})\end{array}$ & $\begin{array}{c}90 \% \\
(\mathrm{n}=10 \mathrm{HH})\end{array}$ \\
\hline & $\mathrm{CDC}$ & $\begin{array}{c}70 \% \\
(\mathrm{n}=10 \mathrm{HH})\end{array}$ & $\begin{array}{c}70 \% \\
(\mathrm{n}=10 \mathrm{HH})\end{array}$ & $\begin{array}{c}60 \% \\
(\mathrm{n}=10 \mathrm{HH})\end{array}$ & $\begin{array}{c}100 \% \\
(\mathrm{n}=10 \mathrm{HH})\end{array}$ & $\begin{array}{c}80 \% \\
(\mathrm{n}=10 \mathrm{HH})\end{array}$ & $\begin{array}{c}100 \% \\
(\mathrm{n}=10 \mathrm{HH})\end{array}$ \\
\hline \multirow{2}{*}{$\begin{array}{l}\text { Village } 2 \text { households } \\
\text { using the Samban- } \\
\text { dou River as primary } \\
\text { water source }\end{array}$} & Traditional & $\begin{array}{c}100 \% \\
(\mathrm{n}=10 \mathrm{HH})\end{array}$ & $\begin{array}{c}100 \% \\
(\mathrm{n}=10 \mathrm{HH})\end{array}$ & $\begin{array}{c}90 \% \\
(\mathrm{n}=10 \mathrm{HH})\end{array}$ & $\begin{array}{c}90 \% \\
(\mathrm{n}=10 \mathrm{HH})\end{array}$ & $\begin{array}{c}100 \% \\
(\mathrm{n}=10 \mathrm{HH})\end{array}$ & $\begin{array}{c}100 \% \\
(\mathrm{n}=10 \mathrm{HH})\end{array}$ \\
\hline & $\mathrm{CDC}$ & $\begin{array}{c}90 \% \\
(\mathrm{n}=10 \mathrm{HH})\end{array}$ & $\begin{array}{c}90 \% \\
(\mathrm{n}=10 \mathrm{HH})\end{array}$ & $\begin{array}{c}90 \% \\
(\mathrm{n}=10 \mathrm{HH})\end{array}$ & $\begin{array}{c}100 \% \\
(\mathrm{n}=10 \mathrm{HH})\end{array}$ & $\begin{array}{c}100 \% \\
(\mathrm{n}=10 \mathrm{HH})\end{array}$ & $\begin{array}{c}100 \% \\
(\mathrm{n}=10 \mathrm{HH})\end{array}$ \\
\hline
\end{tabular}

$H H=$ households

TABLE 7

Poisson regression analysis with $E$. coli average counts in households using the placebo solution as measure for water quality

\begin{tabular}{|l|c|c|c|}
\hline Exposure & IRR & P-value & $\begin{array}{c}\text { 95\% confidence } \\
\text { interval for IRR }\end{array}$ \\
\hline Hand washing vs. no hand washing & 0.58 & 0.031 & $(0.349 ; 0.950)$ \\
\hline CDC water-storage containers vs. traditional water-storage container & 0.98 & 0.941 & $(0.646 ; 1.499)$ \\
\hline Living far $(>100 \mathrm{~m})$ vs. living close $(<100 \mathrm{~m})$ to the river source & 0.85 & 0.623 & $(0.453 ; 1.607)$ \\
\hline Living close $(<100 \mathrm{~m})$ to a tap source vs. living close $(<100 \mathrm{~m})$ to the river source & 0.26 & 0.000 & $(0.132 ; 0.493)$ \\
\hline Living far $(>100 \mathrm{~m})$ from a tap source vs. living close $(<100 \mathrm{~m})$ to the river source & 0.29 & 0.005 & $(0.121 ; 0.681)$ \\
\hline
\end{tabular}

$I R R=$ incidence ratio rate

\section{Association between household demographics and hygiene practices and water quality in the study population (Table 7)}

Results from the household questionnaires were used to assess the association (link) between household demographic and hygiene practices and water quality, measured in terms of $E$. coli counts. Poisson regression which adequately deals with counts and zeros was used. Several factors included in the baseline household questionnaire were considered. However, the factors that were included into the final regression analysis included:

- Practice of hand washing before food preparation

- Container type in use and

- A compounded variable of source and the distance the household is away from the source.

Based on the incidence rate ratios obtained in the analysis, the following could be concluded:

- In the CDC container, E. coli counts were $98 \%$ of that of the traditional container $(\mathrm{P}=0.941)$.

- If hands were washed before food preparation E. coli counts were reduced to $58 \%(\mathrm{P}=0.031)$ of the $E$. coli counts when hands were not washed. Hand washing after defecation and before food preparation is fundamental to food hygiene and several studies have shown that hands could play an important role in the transmission of $E$. coli species (Boyer et al., 1975; Harris et al., 1985). In addition, Lin et al. (2003) have shown that E. coli bacteria are harboured under the fingernails and proper washing with soap could decrease the incidence. This was confirmed by studies showing that hand washing decreases diarrhoeal prevalence by $89 \%$ (Han et al., 1989).

- When living further ( $>100 \mathrm{~m}$ ) away from the river, the $E$. coli counts were $85 \%(\mathrm{P}=0.623)$ of that when living close (within $100 \mathrm{~m}$ ) to the river. This was contrary to the expectation that it should have been higher. Households living far from the primary water source may tend to collect more water and store water for longer periods in containers that are larger than $25 \ell$. The results from this analysis could be explained by the possible settling of the microorganisms at the bottom of these larger containers or because of the natural die-off of $E$. coli bacteria during the long periods of water-storage inside these larger containers (Moyo et al., 2004).

- When living close (within $100 \mathrm{~m}$ ) to a tap source, E. coli counts were only $26 \%(\mathrm{P}<0.000)$ that of $E$. coli counts when living close (within $100 \mathrm{~m}$ ) to the river. This implied that people using an improved source such as the communal taps, will have fewer $E$. coli bacteria compared to people using an unimproved water source such as a river.

- When living further ( $>100 \mathrm{~m})$ away from a tap source, E. coli counts were only $29 \%(\mathrm{P}=0.005)$ of that of $E$. coli counts when living close (within $100 \mathrm{~m}$ ) to the river. This implied that people using an improved source such as the communal taps, will have fewer E. coli bacteria compared to people using an unimproved water source such as a river.

Unhygienic practices in households that could have contributed to the deterioration of the stored water

The questionnaire survey revealed several aspects which might explain the deterioration of the household stored drinking water 
after collection. Many of the people had to walk long distances to obtain water from the source. Approximately $53.3 \%$ of Village 1 households and $36.7 \%$ of Village 2 households had their water source located within 0 to $100 \mathrm{~m}$ from the households with $18.3 \%$ of Village 1 households and $63.3 \%$ of Village 2 households had a water source located between 100 and $500 \mathrm{~m}$ from the household. It was observed that the greater the distance, the longer the water-storage period of the water at the point-of-use. All the households in both study groups stored their water after collection. Different size containers were used for this purpose, ranging from 20 to $50 \ell$ [55\% Village 1 households and $41.7 \%$ Village 2 households], 50 to $100 \ell$ [5\% Village 1 households; $13.3 \%$ Village 2 households], 100 to $200 \ell$ [11.7\% Village 1 households; $15 \%$ Village 2 households], to $>200 \ell$ [28.3\% village 1 households; $30 \%$ village 2 households].

The method used to obtain water from the water-storage container could contribute to contamination and the spreading of potential disease-causing microorganisms between members of the same household. Approximately $90 \%$ of Village 1 households and $96.7 \%$ of Village 2 households used a mug to collect water from the water-storage container. Observations showed that the mug was not washed every time it was used and was left next to the water-storage container where animals, insects and small children had access to it. Jagals et al. (1999) and Sobsey (2002) indicated that faecally contaminated hands of household members who do not apply personal hygiene practices can contribute to water contamination. In this study population only $1.7 \%$ of Village 1 households had a place near the toilet to wash hands. The survey further indicated that approximately $48.3 \%$ of Village 1 households and $28.3 \%$ of Village 2 households washed hands after being to the toilet. Observations indicated that only $3.3 \%$ of Village 1 households and $1.7 \%$ of Village 2 households had toilet paper available in the toilet. However, between 95 and $96.7 \%$ of the study population in both villages, reported to wash their hands before eating, while only $5 \%$ of Village 1 households and $11.7 \%$ of Village 2 households reported to wash hands before they prepared food. This practice was another potential risk of faecal contamination of food and water supplies in these households.

The water-storage containers were exposed to contamination from dust, animals, insects, flies and children. According to the survey $30 \%$ of Village 1 households and $56.7 \%$ of Village 2 households stored their water containers indoors with a closed lid, while $56.7 \%$ of Village 1 households and $36.7 \%$ of Village 2 households stored their drinking water containers indoors in open containers. Further observations indicated that $15 \%$ of Village 1 households and $13.3 \%$ of Village 2 households had loose covers on their water-storage containers. Approximately $58.3 \%$ of Village 1 households and $31.7 \%$ of Village 2 households had no cover on the water-storage containers. Earlier studies by Dunker (2001) and Nala et al. (2003) showed that open containers were more at risk of being contaminated by human and animals than containers which were covered.

Inadequate or no treatment of stored drinking water remains a problem in low socio-economic households. The majority of Village 1 (93.3\%) and Village $2(100 \%)$ households did not use any treatment before consuming the water, while $5 \%$ and $1.7 \%$ respectively of the Village 1 households indicated that they used boiling and sand filtration as treatment of their drinking water. This indicated a lack of knowledge and education by the households on the health risks associated with waterborne diseases.

Furthermore, observations made by the interviewers included the following: $35 \%$ of Village 1 households and $8.3 \%$ of Village 2 households had a dirty yard of which $43.3 \%$ of Village 1 and $8.3 \%$ of Village 2 households had flies present in the yard. A study by Alam and Zurek (2004) has shown that houseflies carry virulent $E$. coli $\mathrm{O} 157: \mathrm{H} 7$ in areas where cattle are kept and this may play an important role in the transmission of this pathogen between cattle and to the household environment. In Village 1, 35\% households had dirty kitchens while $40 \%$ of the households had flies present in the kitchen. In Village $2,10 \%$ of the households had dirty kitchens while $5 \%$ of the households had flies present in the kitchen. Garbage containers were absent in all Village 1 households and $98.3 \%$ of Village 2 households. Approximately $51.7 \%$ of Village 1 households and $36.7 \%$ of Village 2 households had flies in the toilet. Only $63.3 \%$ of Village 1 households and $36.6 \%$ of Village 2 households had a pit latrine. However, $35 \%$ of Village 1 households and $61.7 \%$ of Village 2 households had no toilet facilities and used the bush near their households to relieve themselves.

\section{Conclusions}

The microbiological quality of the water sources used for domestic purposes by the 2 study populations was above South African safe water guideline values for domestic drinking water and posed a potential health risk to the consumers. The increase in the indicator microorganism counts in the traditional and CDC safe water-storage containers indicated secondary faecal contamination at the point-of-use due to unhygienic water-handling practices (i.e. unsanitary use of utensils and hands touching the water). In addition, no statistical differences were seen in the prevalence of indicator microorganisms between the traditional and the CDC safe water-storage containers using the placebo sodium hypochlorite solution in both study populations. This indicated that the CDC safe container as a single intervention without a sodium hypochlorite solution was not effective in the prevention of secondary contamination and did not significantly improve the microbiological quality of the stored drinking water. This is in agreement with an earlier study conducted by Quick et al.(1996) who indicated that the CDC safe water-storage container without the sodium hypochlorite intervention is not very effective in reducing the risk associated with waterborne diseases.

This is the first study carried out in South Africa to evaluate the impact of the CDC safe water-storage container with or without the addition of a $1 \%$ or a $3.5 \%$ sodium hypochlorite solution on water supplies stored in rural households in the Vhembe region of the Limpopo Province. The results indicate that both the $1 \%$ and $3.5 \%$ sodium hypochlorite solution interventions reduced the potential risk of waterborne diseases by improving the microbiological quality of stored household drinking water in the CDC safe water-storage containers to undetectable counts. These results are in agreement with other studies conducted in developing countries where the CDC safe water-storage container together with a sodium hypochlorite solution was assessed as a combined intervention strategy (Macy and Quick, 1998; Semenza et al., 1998; CDC, 2001; Sobsey, 2002; Sobsey et al., 2003). However, the microbiological quality of stored household drinking water in the traditional water-storage containers was also reduced to undetectable counts with the use of the $1 \%$ and the $3.5 \%$ sodium hypochlorite solutions. This is in agreement with earlier studies suggesting that when the traditional household water-storage container is handled correctly and covered properly, the microbiological quality of the stored drinking water can be protected (Hammad and Dirar, 1982; Deb et al., 1986; Pinfold, 1990). 
It also confirms that the traditional water-storage container can be used effectively by households which cannot afford the CDC safe water-storage container or another point-of-use treatment system.

Although this study included an education intervention on the use and cleaning of the CDC safe water-storage container and the addition of the correct amounts of sodium hypochlorite solutions to the stored water, the survey indicated an urgent need for behavioural changes in these communities. It seemed that appropriate hygiene practices were not practiced due to financial burdens on the family, different cultural beliefs and the lack of adequate sanitation and water infrastructures. Several studies have shown that the addition of a sodium hypochlorite solution to stored drinking water reduced diarrhoea between 44\% and 48\% (Quick et al., 1999; Quick et al., 2002). It is however, essential that point-of-use and social education interventions at the household level should be implemented as a package and promoted on a larger scale in rural communities to prevent the outbreak of waterborne diseases (Mermin et al., 2005).

\section{Acknowledgements}

Mega Pak, Midrand, South Africa, supplied the CDC safe water-storage containers. TS Marketing, Polokwane and Reckitt Benkiser in Boksburg, RSA supplied the sodium hypochlorite solutions. Dr R Quick from the Centres of Disease Control, Atlanta, USA provided valuable advice.

\section{References}

ALAM MJ and ZUREK L (2004) Association of Escherichia coli O157:H7 with houseflies on a cattle farm. Appl. Environ. Microbiol. 70 7578-7580.

ALLWOOD PB, YASHPAL SM, HEDBERG CW and GOAL SM (2003) Survival of F-specific RNA coliphage, feline calici virus and Escherichia coli in water: A comparative study. Appl. Environ. Microbiol. $695705-5710$

ATKIN E, BENTON WH and HILL WF (1971) Enteric viruses in ground and surface waters: A review of their occurrence and survival. Proc. $13^{\text {th }}$ Water Quality Conf. University of Illinois. Bulletin 69 59-74.

BARTRAM J, COTRUVO J, EXNER M, FRICKER C and GLASMACHER A (2003) Heterotrophic plate counts and drinking-water safety. WHO X 1-256.

BOYER KM, PETERSEN NJ, FARZANETH I, PATTISON CP, HART MC and MAYNARD JE (1975) An outbreak of gastroenteritis due to E. coli 0142 in a neonatal nursery. J. Pediat. 86 919-927.

CARLSSON FHH (2003) Elementary Handbook of Water Disinfection. WRC Report No. TT 205/03. Water Research Commission, Pretoria, South Africa.

CDC (2001) Safe Water Systems for the Developing World: A Handbook for Implementing Household Based Water Treatment and Safe Water-Storage Projects. Department of Health and Human Services, Centers for Disease Control and Prevention, Atlanta, USA. $187 \mathrm{pp}$.

CLASEN T, ROBERTS I, RABIE T, SMIDT W and CAIRNCROSS $S$ (2006) Interventions to improve water quality for preventing diarrhoea. Cochrane Database of Systematic Reviews 2006, Issue 3. Art. No.: CD004794. DOI: 10.1002/14651858.CD004794.pub2. John Wiley Publishers, USA. 99 pp.

CONROY RM, MEEGAN ME, JOYCE T, McGUIGAN KG and BARNES J (1996) Solar disinfection of drinking water and diarrhoea in Masaai children: A controlled field trial. Lancet 348 1695-1697.

CRUMP JA, OTIENO PO, SLUTSKER L, KESWICK BH, ROSEN DH, HOEKSTRA RM, VALULE JM and LUBY SP (2005) House- hold based treatment of drinking water with flocculent disinfectant for preventing diarrhoea in areas with turbid source water in rural western Kenya: cluster randomised controlled trial. URL: BMJ, DOI:10.1136/bmj.38512.618681.EO (published 26 July 2005).

DANIELS NA, SIMONS SL, RODRIQUES A, GUNNLAUGSSON G, FORESTER TS, WELLS JG, HUTWAGNER L, TAUXE RV and MINTZ ED (1999) First do no harm: Making oral rehydration solutions safer in a cholera epidemic. Am. J. Trop. Med. Hyg. 60 1051-1055

DEB BC, SIRCAR BK, SENGUPTA PG, DE SP, SAHA MR and PAL SC (1986) Intra-familial transmission of Vibrio cholerae biotype Eltor in Calcutta slums. Ind. J. Med. Res. 76 814-819.

DUNKER L (2001) The KAP Tool for Hygiene. A Manual on: Knowledge, Attitudes and Practices in the Rural Areas of South Africa. WRC Report No. TT 144/00. Water Research Commission, Pretoria, South Africa.

DWAF (DEPARTMENT OF WATER AFFAIRS AND FORESTRY) (1996) South African Water Quality Guidelines. Volume 2. Domestic Use. The Government Printer, Pretoria, South Africa.

EDBERG SC, RICE EW, KARLIN RJ and ALLEN MJ (2000) Escherichia coli: The best biological drinking water indicator for public health concern. J. Appl. Environ. Microbiol. 88 106S-116S.

ENGELBRECHT RS, WEBER MJ, SALTER BL and SCHMIDT CA (1980) Comparative inactivation of viruses by chlorine. J. Appl. Environ. Microbiol. 40 249-256.

FEWTRELL L, KAUFMANN RB, ENANAORIA W, HALLER L and COLFORD JM (2005) Water, sanitation and hygiene interventions to reduce diarrhoea in less developed countries: a systematic review and meta-analysis. Lancet 5 42-52.

FREESE SD and NOZAIC DJ (2004) Chlorine: Is it really so bad and what are the alternatives? Water SA 30 (5) 18-24.

GARRETT V, OGUTU P, MABONGA P, OMBEKI S, MWAKI A, ALUOCH G, PHELAN M and QUICK RE (2008) Diarrhoea prevention in a high-risk rural Kenyan population through pointof-use chlorination, safe water water-storage, sanitation and rain water harvesting. Epidemiol. Infect. 136 (11) 1463-1471.

GILMAN RH and SKILLICORN P (1985) Boiling of drinking water: Can a fuel-scarce community afford it? Bull. WHO 63 157-163.

GRABOW WOK, HOLTZHAUSEN CS and DE VILLIERS JC (1993) Research on Bacteriophages as Indicators of Water Quality. WRC Report No. 321/1/93. Water Research Commission, Pretoria, South Africa.

HAMMAD ZH and DIRAR HA (1982) Microbiological examination of sebeel water. Appl. Environ. Microbiol. 43 1238-1243.

HAN A, OO K, MIDORIKAWA Y and SHWE S (1989) Contamination of drinking water during collection and water-storage. Trop. Geograph. Med. 41 138-140.

HARRIS JR, MARIANO J, WELLS JG, PAYNE BJ, DONNELL HD and COHEN ML (1985) Person-to-person transmission in an outbreak of enteroinvasive Escherichia coli. Am. J. Epidemiol. 122 245-252.

ISO (1995) Water quality-Detection and Enumeration of Bacteriophages-Part 1: Enumeration of F-specific RNA Bacteriophages. Doc ISO 10705-1. International Organization for Standardization, Geneva.

ISO (2000) Water quality-Detection and Enumeration of Bacteriophages-Part 2: Enumeration of Somatic Bacteriophages. Doc ISO 10705-2. International Organization for Standardization, Geneva.

JAGALS P, BOKATO TC and GRABOW WOK (1999) Changing consumer water-use patterns and their effect on microbiological water quality as a result of an engineering intervention. Water $S A$ 25 297-300.

KUHNERT P, BOERLIN P and FREY J (2000) Target genes of virulence assessment of Escherichia coli isolates from water, food and environment. Fed. Eur. Microbiol. Soc. Rev. 24 107-117.

LECLERC H, EDBERG S, PIERZO V and DELATTRE JM (2000) A review: Bacteriophages as indicators of enteric viruses and public health risk in groundwaters. J. Appl. Microbiol. 88 5-21.

LIN CM, WU FM, KIM HK, DOYLE MP, MICHAEL BS and WILLIAMS LK (2003) A comparison of hand washing techniques to remove Escherichia coli and Caliciviruses under natural or artificial fingernails. J. Food Prot. 66 2296-2301. 
LISTLE JT, SMITH JJ, EDWARDS DD and McFETERS GA (2004) Occurrence of microbial indicators and Clostridium perfringens in wastewater, water column samples, sediments, drinking water and Weddell seal faeces collected at McMurdo Station, Antarctica. Appl. Environ. Microbiol. 70 7269-7276.

LUBY SP, AGBOATWALLA M, RAZA A, SOBEL J, MINTZ E, BAIER K, RAHBAR M, QURESHI SM, HASSAN R, GHOURI F, HOEKSTRA RM and GANGAROSA E (2001) A low-cost intervention for cleaner drinking water in Karachi, Pakistan. Inter. J. Infect. Dis. 5 144-150.

LULE JR, MERMIN J, EKWARU JP, MALAMBA S, DOWNING R, RANSOM R, NAKANJAKO D, WAFULA W, HUGHES P, BUNNELL R, KAHARUZA F, COUTINHO A, KIGOZI A and QUICK $R$ (2005) Effect of home-based water chlorination and safe waterstorage on diarrhea among persons with human immunodeficiency virus in Uganda. Am. J. Trop. Med. Hyg. 73 (5) 926-933.

MAC FADDIN JF (1980) Biochemical Tests for Identification of Medical Bacteria $\left(2^{\text {nd }}\right.$ edn.) Williams and Wilkons, Baltimore, USA. 527 pp.

MACY JT and QUICK RE (1998) Letter to the Editors: Evaluation of a novel drinking water treatment and water-storage intervention in Nicaragua. Pan Am. J. Pub. Health 3 135-136.

MAKUTSA P, NZAKU K, OGUTU P, BARASA P, OMBEKI S, MWAKI A and QUICK RE (2001) Challenges in implementing a point-of-use water quality intervention in rural Kenya. Am. J. Pub Health 91 (10) 1571-1573.

MERMIN J, BUNELL R, LULE J, OPIO A, GIBBONS A, DYBUL M and KAPLAN J (2005) Developing an evidence-based, preventative care package for persons with HIV in Africa. Am. J. Trop. Med. Hyg. 10 961-970.

MINTZ ED, REIFF FM, ROBERT V and TAUXE MD (1995) Safe water treatment and water-storage in the home: A practical new strategy to prevent waterborne disease. J. Am. Med. Assoc. 273 948-953.

MONG Y, KAISER R, RASOATIANA DI, RAZAFIMBOLOLONA I and QUICK RE (2001) Impact of the safe water system on water quality in cyclone-affected communities in Madagascar. Am. J. Pub. Health 91 1577-1579.

MOYO S, WRIGHT J, NDAMBA J and GUNDRY S (2004) Realising the maximum health benefit from water quality improvements in the home: A case study from Zaka District, Zimbabwe. Phys. Chem. Earth 29 1295-1299.

NALA NP, JAGALS P and JOUBERT G (2003) The effect of a waterhygiene educational programme on the microbiological quality of container-stored water in households. Water SA 29 171-176.

PATEL M and ISAACSON M (1989) Survival of Vibrio cholerae in African domestic water water-storage containers. S. Afr. Med.J. 76 365-367.

PAYMENT P, RICHARDSON L, SIEMIATYCHI J, DEWAR R, EDWARDS M and FRANCO E (1991) A randomised trial to evaluate the risk of gastrointestinal disease due to consumption of drinking water meeting current microbiological standards. Am. J. Pub. Health 81 703-708.

PAYMENT P and FRANCO E (1993) Clostridium perfringens and somatic coliphages as indicators of the efficiency of drinking water treatment for viruses and protozoan cysts. Appl. Environ. Microbiol. 59 2418-2424.

PINFOLD J (1990) Faecal contamination of water and fingertip-rinses as a method for evaluating the effect of low-cost water supply and sanitation activities on faeco-oral disease transmission (II). A hygiene intervention study in rural north-east Thailand. Epidemiol. Infect. 105 377-389.

QUICK RE, GERBER ML and PALACOIS AM (1996) Using a knowledge, attitude and practices survey to supplement findings of an outbreak investigation: Cholera prevention measures during the 1991 epidemic in Peru. Intern. J. Epidemiol. 25 872-878.

QUICK RE, VENCZEL LV, MINTZ ED, SOLETO L, APARICIO J, GIRONAZ M, HUTWAGNER L, GREENE K, BOPP C, MALONEY K, CHAVEZ D, SOBSEY M and TAUXE RV (1999) Diarrhoea prevention in Bolivia through point-of-use water treatment and safe water-storage: A promising new strategy. Epidemiol. Infect. 122 83-90.
QUICK RE, KIMURA A, THEVUS A, TEMBO M, SHAMPUTA I, HUTWAGNER L and MINTZ E (2002) Diarrhea prevention through household-level water disinfection and safe water-storage in Zambia. Am. J. Trop. Med. Hyg. 66 584-589.

REIFF FM, ROSES M, VENCZEL L, QUICK R and WITT VM (1996) Low cost safe water for the world: A practical interim solution. J. Pub. Health Pol. 17 389-408.

RELLER ME, MENDOZA CE, LOPEZ MB, ALVAREZ M, HOEKSTRA RM, OLSON CA, BAIER KG, KESWICK BH and LUBY SP (2003) A randomised trial of household based flocculant disinfectant drinking water treatment for diarrhoea prevention in rural Guatemala. Am. J. Trop. Med. Hyg. 69 411-419.

SABS (2001) Specifications for Drinking Water (edn. 5). SANS 2412001. South African Bureau of Standards, Pretoria, South Africa. $9 \mathrm{pp}$.

SATTAR SA (1981) Virus survival in receiving waters. In: Goddard M and Butler M (eds.) Viruses and Wastewater Treatment. Pergamon Press Inc., Elmsford, New York. 91-108.

SEMENZA JC, ROBERTS L, HENDERSON A, BOGAN J and RUBIN CH (1998) Water distribution system and diarrheal transmission: A case study in Uzbekistan. Am. J. Trop. Med. Hyg. 59 941-946.

SCHAPER M, DURAN AE and JOFRE J (2002) Comparative resistance of phage isolates of four genotypes of F-specific RNA bacteriophages to various inactivation processes. Appl. Environ. Microbiol. 68 3702-3707.

SHRESTHA RK, MARSEILLE E, KAHN JG, LULE JR, PITTER C, BLANDFORD JM, BUNNELL R, COUTINHO A, KIZITO F, QUICK R and MERMIN J (2006) Cost-effectiveness of home-based chlorination and safe water water-storage in reducing diarrhea among HIV-affected households in rural Uganda. Am. J. Trop. Med. Hyg. 74(5) 884-890.

SKRABER S, GASSILLOUD B, SCHWARTZBROD L and GANTZER $C$ (2004) Survival of infectious poliovirus-1 in river water compared to the persistence of somatic coliphages, thermotolerant coliforms and poliovirus-1 genome. Water Res. 38 2927-2933.

SOBEL J, MAHON B, MENDOZA CE, PASSARO D, CANO F, BAIER K, RACIOPPI F, HUTWAGNER L and MINTZ E (1998) Reduction of fecal contamination of street-vended beverages in Guatemala by a simple system for water purification and waterstorage, handwashing and beverage water-storage. Am. J. Trop. Med. Hyg. 59 380-387.

SOBSEY MD (2002) Managing water in the home: Accelerated health gains from improved water supply. World Health Organization Sustainable Development and Healthy Environments. World Health Organization, Geneva. WHO/SDE/WSH/02.07.

SOBSEY MD, HANDZEL T and VENCZEL L (2003) Chlorination and safe water-storage of household drinking water in developing countries to reduce waterborne disease. Water Sci. Technol. 47 221-228.

STANDARD METHODS (1995) Standard Methods for the Examination of Water and Wastewater $\left(19^{\text {th }}\right.$ edn.) Eaton AD, Clesceri LS and Greenberg AE (eds.). American Public Health Association, Washington, DC.

SUTTON S and MUBIANA D (1989) Household water quality in rural Zambia. Waterlines 8 88-89.

UYS M (1999) Molecular Characterization of F-specific RNA Phages in South Africa. M.Sc. Thesis in Medical Virology. Department of Medical Virology, Univ. of South Africa, Pretoria, South Africa

VAUGHN JM, CHEN YS and MCHARREL ZT (1986) Inactivation of human and simian rotaviruses by chlorine. Appl. Environ. Microbiol. 51 391-394.

WHO (1996) Guidelines for Drinking-Water Quality (2 ${ }^{\text {nd }}$ edn.) Volume 2. Health Criteria and Other Supporting Information. World Health Organization, Geneva. 973 pp.

WHO (2002a) Water for Development: A Practical Advocacy Guide for World Water Day 2002. URL: http://www.worldwaterday.org/ advocacy/adv.html (Accessed on 20 February 2007).

WHO (2002b) Heterotrophic Plate Count Measurement in Drinking Water Safety Management, Protection of the Human Environment. Water, Sanitation and Health. World Health Organization, Geneva. WHO/SDE/WSH/02.10. 